\title{
Ciclo orçamentário e prioridades das políticas federais para o esporte e lazer no Brasil (2004-2011)
}

http://dx.doi.org/10.11606/1807-5509201900040531

\section{Resumo}

Este estudo teve por objetivo investigar as prioridades e a distribuição orçamentária das políticas federais do Ministério do Esporte no decorrer dos processos de elaboração e execução orçamentária dos anos de 2004 a 2011. Esta pesquisa, de cunho quantitativo descritivo, teve como fonte de dados o portal "SIGA Brasil". Concluimos que a cada etapa do processo orçamentário, a proposta acordada para a função "Desporto e Lazer" apresentou especificidades no que se referiu às prioridades das políticas federais para o esporte e lazer, não havendo um quadro prioritário único que tenha norteado os processos de elaboração e execução orçamentária. A inexistência de um padrão no financiamento para a área que tenha perpassado as diferentes etapas do processo orçamentário, bem como a falta de regularidade na liquidação de recursos revela que o governo federal não teve, durante o período analisado, uma política clara para o setor esportivo.

Palavras-chave: Orçamento; Financiamento Governamental; Política Pública; Esporte.

\section{Introdução}

A Constituição Federal de 1988 instituiu como dever do Estado brasileiro o fomento às práticas esportivas formais e não formais como direito de cada cidadão brasileiro ${ }^{1}$. Ainda de acordo com a legislação brasileira, os recursos necessários para este fomento devem ser assegurados através de programas governamentais dos orçamentos da União, dos Estados, do Distrito Federal e dos Municípios². Estes recursos encontram-se normatizados pelos Planos Plurianuais (PPA), Lei de Diretrizes Orçamentárias (LDO) e, especialmente, pela Lei Orçamentária Anual (LOA) e se caracterizam em um financiamento público direto - "financiamento orçamentário".

O fomento ao esporte no Brasil também deve ser assegurado por meio de um financiamento público indireto - "financiamento extraorçamentário". Estes recursos não transitam pelo orçamento público e são provenientes de fundos desportivos, concursos de prognósticos, doaçōes, patrocínios e legados, incentivos fiscais previstos em lei, e outras fontes ${ }^{2}$. Dentre estes, podemos destacar aqueles provenientes da Lei $n^{\circ}$. 9.615/1998 (Lei Pelé), Lei $n^{\circ}$. 10.264/2001 (Lei Agnelo/Piva), Lei $n^{\circ}$. 11.438/2006 (Lei de Incentivo ao Esporte) e Lei $\mathrm{n}^{\circ} .11 .345 / 2006$ (Timemania). De acordo com a legislação brasileira, tanto a destinação dos recursos orçamentários quanto dos extraorçamentários devem observar a promoção prioritária do esporte educacional $^{1,2}$.

Apesar de o esporte e o lazer estarem instituídos legalmente como direitos e que o esporte educacional tenha prioridade na destinação dos recursos públicos, diversos estudos sobre o financiamento de políticas federais para o esporte e lazer têm indicado que a distribuição dos recursos públicos tem tomado o esporte de rendimento como dimensão privilegiada pelo Poder Público ${ }^{3-8}$. Vários estudos indicam ainda que a realização de grandes eventos esportivos no país tem se configurado como prioridade nas políticas federais para o esporte e lazer lat, $^{3-12}$. Embora os estudos citados acima tenham tratado do financiamento orçamentário das políticas federais para o esporte e lazer, nenhum destes teve como 
foco de análise a evolução do financiamento para o esporte e lazer no decorrer das etapas de elaboração e execução orçamentária. Considerando-se esta lacuna, esta pesquisa teve por objetivo investigar as prioridades e a distribuição orçamentária das políticas federais do Ministério do Esporte (ME) para o esporte e lazer no decorrer dos processos de elaboração e execução orçamentária dos anos de 2004 a 2011.

Tal como os demais fatores que resultam em uma política (policy), o orçamento decorre de escolhas, preferências e decisões tomadas pelos agentes do âmbito político (politics) ao longo do sistema político (polity). Neste sentido, para além do seu aspecto contábil e técnico, o orçamento é resultado de uma escolha política que reflete as demandas consideradas como mais importantes pelo governo ${ }^{13}$. Deste modo, ao analisarmos

\section{Método}

Este estudo se caracterizou como uma pesquisa quantitativa descritiva de cunho exploratório que teve por objetivo investigar as prioridades e a distribuição do financiamento orçamentário das políticas federais do Ministério do Esporte (ME) para o esporte e lazer no decorrer dos anos de 2004 a 2011, tendo como foco principal as fases de elaboração e de execução das leis orçamentárias anuais do Orçamento Geral da União (OGU) da função "Desporto e Lazer".

Ao elegermos como foco de análise a função "Desporto e Lazer", optamos por investigar os recursos orçamentários pela sua classificação funcional. Esta classificação se reporta à área de atuação governamental em que a despesa será realizada e guarda estreita ligação com as áreas de atuação dos respectivos ministérios. Portanto, optamos por centrar a análise nas despesas governamentais que foram direcionadas para a área do esporte e lazer e que foram diretamente vinculadas ao órgão responsável pela administração federal do esporte no país, o ME.

Ao referirmo-nos aos recursos orçamentários na fase de elaboração, investigamos os recursos federais do: (1) Projeto de Lei Orçamentária Anual (PLOA), relativo a proposta elaborada pelo Poder Executivo e encaminhada ao Poder Legislativo; e (2) Lei Orçamentária Anual (LOA), referente a proposta orçamentária sancionada como lei que a distribuição e a evolução do financiamento para o esporte e lazer no decorrer do processo orçamentário, este estudo buscou averiguar se de fato as assertivas de que o financiamento das políticas federais para o esporte e lazer tem privilegiado o esporte de alto rendimento e a realização de megaeventos esportivos procedem.

Estudos relativos ao financiamento do esporte no Brasil se configuram como demandas na produção científico-acadêmica em políticas públicas de esporte e lazer no Brasil ${ }^{14}$. Deste modo, esta pesquisa, de cunho quantitativo descritivo, visa contribuir para com a ainda escassa produção científica sobre o financiamento do esporte e do lazer no país. A análise aqui proposta poderá servir como base para futuras análises e discussões sobre o financiamento do esporte e lazer no Brasil e sobre a gestão das políticas públicas de esporte e lazer no país.

sumariza o total das dotações presentes no PLOA, as alterações propostas pelos parlamentares e o veto ou não do Poder Executivo. Já no processo de execução orçamentária, levantamos os recursos: (1) autorizados, relativo ao total de créditos orçamentários autorizados pela LOA acrescido el ou deduzido dos créditos adicionais e/ou bloqueios durante o exercício financeiro ${ }^{a}$; e (2) liquidados, relativo ao total de recursos que passaram pelo processo de empenho e verificação do direito adquirido pelo credor.

Não investigamos a execução dos recursos empenhados porque não houve diferença significativa entre os recursos empenhados e liquidados durante o período que nos propusemos a estudar. Ou seja, verificamos que $99,99 \%$ de todos os recursos empenhados foram liquidados. Também não nos propomos a investigar o montante de recursos "pagos", os quais se referem ao total de recursos orçamentários entregues ao credor, por meio de crédito em conta, ordem de pagamento ou cheque nominativo. Em decorrência de eventuais atrasos na execução dos recursos previstos, o pagamento dos recursos orçamentários liquidados pode não ocorrer no seu respectivo exercício financeiro. Eles podem ser pagos em anos posteriores por meio das categorias "restos a pagar pagos" e/ou "despesas de exercícios anteriores". Considerando que os recursos "pagos" podem não representar o montante de 
recursos orçamentários que foi executado em um exercício financeiro, e considerando que buscamos averiguar a distribuição de recursos e as prioridades orçamentárias dos exercícios financeiros de 2004 a 2011, optamos por investigar os recursos liquidados e não os pagos.

O presente trabalho, portanto, tratou da execução orçamentária e não da execução financeira. Embora intimamente relacionados, os mesmos se referem a processos distintos. A execução orçamentária se refere à movimentação do orçamento por meio dos registros das receitas arrecadadas, bem como dos empenhos das despesas, respeitando-se a autorização de despesas existentes. Já a execução financeira diz respeito ao recolhimento das receitas e pagamento das despesas através da movimentação de recursos - dinheiro ou saldo de disponibilidade bancária ${ }^{16}$.

O recorte temporal deste estudo foi de 2004 a 2011. Escolhemos o ano de 2004 como o primeiro ano de coleta de dados, pois este ano se apresenta como o primeiro em que o esporte se insere no planejamento governamental enquanto objeto único de um ministério, neste caso, no ME. Este recorte temporal também leva em consideração o processo de planejamento e execução no decorrer de dois planos de governo: "Plano Brasil de Todos: participação e inclusão (2004-2007)" e "Plano Desenvolvimento com Inclusão Social e Educação de Qualidade (2008-2011)". Os dados referentes ao plano subsequente, "Plano Mais Brasil (20122015)" não estavam disponibilizados em sua completude no momento da coleta (2014), por isso não integraram o escopo deste trabalho. O período selecionado se mostrou propício para interessantes análises, uma vez que ao mesmo tempo em que este período foi marcado pela criação de uma pasta específica para tratar do fomento ao esporte no país, ele também foi marcado pela realização dos XV Jogos Pan-americanos e Parapan-Americanos (Rio 2007), e preparação da Copa do Mundo de Futebol Masculino da FIFA (Brasil 2014) e dos
Jogos Olímpicos e Paralímpicos (Rio 2016).

A coleta dos dados orçamentários teve como fonte principal o portal SIGA Brasil - Sistema de Informaçôes Orçamentárias Gerenciais Avançadas . Através da opção "acesso livre", salvamos os dados dos anos 2004 a 2011 em ".xls" no computador de maneira individual e em seguida os organizamos em tabelas de acordo com os objetivos desta pesquisa.

Tendo em vista as mudanças efetuadas pelo governo federal na proposição dos programas da função "Desporto e Lazer" no decorrer dos diferentes planos governamentais do período analisado, optamos por padronizar a denominação dos programas e agrupar as suas dotações orçamentárias quando estas se referiam a um mesmo programa. Deste modo, a análise da programação orçamentária da função "Desporto e Lazer" abrangeu dez programas governamentais: 1) "Brasil no Esporte de Alto Rendimento" (2004-2007)/"Brasil no Esporte de Alto Rendimento - Brasil Campeão" (2008-2011); 2) "Esporte e Lazer na Cidade" (2004-2007)/"Esporte e Lazer da Cidade" (20082011); 3) "Segundo Tempo" (2004-2007)/"Vivência e Iniciação Esportiva Educacional - Segundo Tempo" (2008-2011); 4) "Inserção Social pela Produção de Material Esportivo" (2004-2007)/"Inclusão Social pelo Esporte" (2008-2011); 5) "Identidade Étnica e Patrimônio Cultural dos Povos Indígenas" (20052007) /"Proteção e Promoção dos Povos Indígenas" (2008-2011); 6) "Rumo ao Pan 2007" (2004-2007); 7) "Esportes de Criação Nacional e de Identidade Cultural” (2004) ; 8) "Gestão das Políticas de Esporte e de Lazer" (2004-2007)/“Gestão das Políticas de Esporte e de Lazer” (2008-2011); 9) "Apoio Administrativo" (2004-2007)/“Apoio Administrativo" (2008-2011); e 10) "Operações especiais: outros encargos sociais" (2010-2011)e.

Para o auxílio da análise quantitativa descritiva, utilizamos os programas Microsoft Office Excel (versão 2007) e Statistical Package for the Social Sciences (SPSS) (versão 22).

\section{Resultados e Discussão}

\section{Elaboração orçamentária da função "Desporto e Lazer"}

A Constituição Federal de 1988 designou ao Poder Executivo a responsabilidade sobre a iniciativa da elaboração do orçamento público brasileiro ${ }^{1}$. Sendo assim, o processo de elaboração da programação orçamentária das políticas federais tem início no Ministério do Planejamento, Orçamento e Gestão (MPOG), mais especificamente na Secretaria de Orçamento Federal (SOF). Baseada nas informações das leis orçamentárias precedentes, a SOF faz uma 
estimativa das receitas e despesas obrigatórias de cada ministério e estabelece limites orçamentários a cada um dos órgãos setoriais s $^{\mathrm{f}}$ ara que estes elaborem uma programação orçamentária de cada programa e ação de suas unidades orçamentárias ${ }^{g}$. Feito isso, as propostas dos órgãos setoriais são reunidas pela SOF em uma única proposta em formato de projeto de lei (PLOA).

No período de 2004 a 2011, o PLOA elaborado pelo Poder Executivo destinou R \$ 3,5 bilhões para a função "Desporto e Lazer". A evolução das propostas orçamentárias indicou que não houve um padrão de crescimento contínuo de recursos para a área e nem a priorização de um único programa governamental. Apesar de os valores cresceram no decorrer dos planos de governo, no período de transição de um plano de governo para o outro houve um decréscimo dos recursos destinados para a área pelo PLOA. De 2007 para 2008, os valores do PLOA para a área decresceram 36,5\%. Esta queda esteve diretamente relacionada com a retirada do "Rumo ao Pan 2007" do planejamento orçamentário da área. No PPA 2004-2007, este programa foi responsável por $54,8 \%$ dos recursos do PLOA.

Também verificamos que o PLOA elaborado pelo Poder Executivo foi marcado por um crescimento expressivo dos recursos em 2011. Este crescimento esteve diretamente ligado ao crescimento de recursos destinados ao "Brasil no Esporte de Alto Rendimento". Dos R \$ 879 milhões de recursos adicionais designados pelo Poder Executivo para a proposta orçamentária para a área em 2011, R\$ 774 milhôes, aproximadamente $88,2 \%$, foi proveniente de incrementos no "Brasil no Esporte de Alto Rendimento".

TABELA 1 -Dotações do projeto de Lei Orçamentária Anual (PLOA) da função "Desporto e Lazer" de 2004 a 2011

\begin{tabular}{ccc}
\hline Ano & R\$ PLOA & Variação do PLOA anterior \\
\hline 2004 & $130.799 .667,00$ & - \\
2005 & $170.591 .077,00$ & $+30,4 \%$ \\
2006 & $386.589 .281,00$ & $+126,6 \%$ \\
2007 & $447.251 .328,00$ & $+15,7 \%$ \\
2008 & $284.206 .178,00$ & $-36,5 \%$ \\
2009 & $384.646 .070,00$ & $+35,3 \%$ \\
2010 & $406.198 .137,00$ & $+5,6 \%$ \\
2011 & $1.285 .363 .782,00$ & $+216,4 \%$ \\
\hline
\end{tabular}

Total $3.495 .645 .520,00$

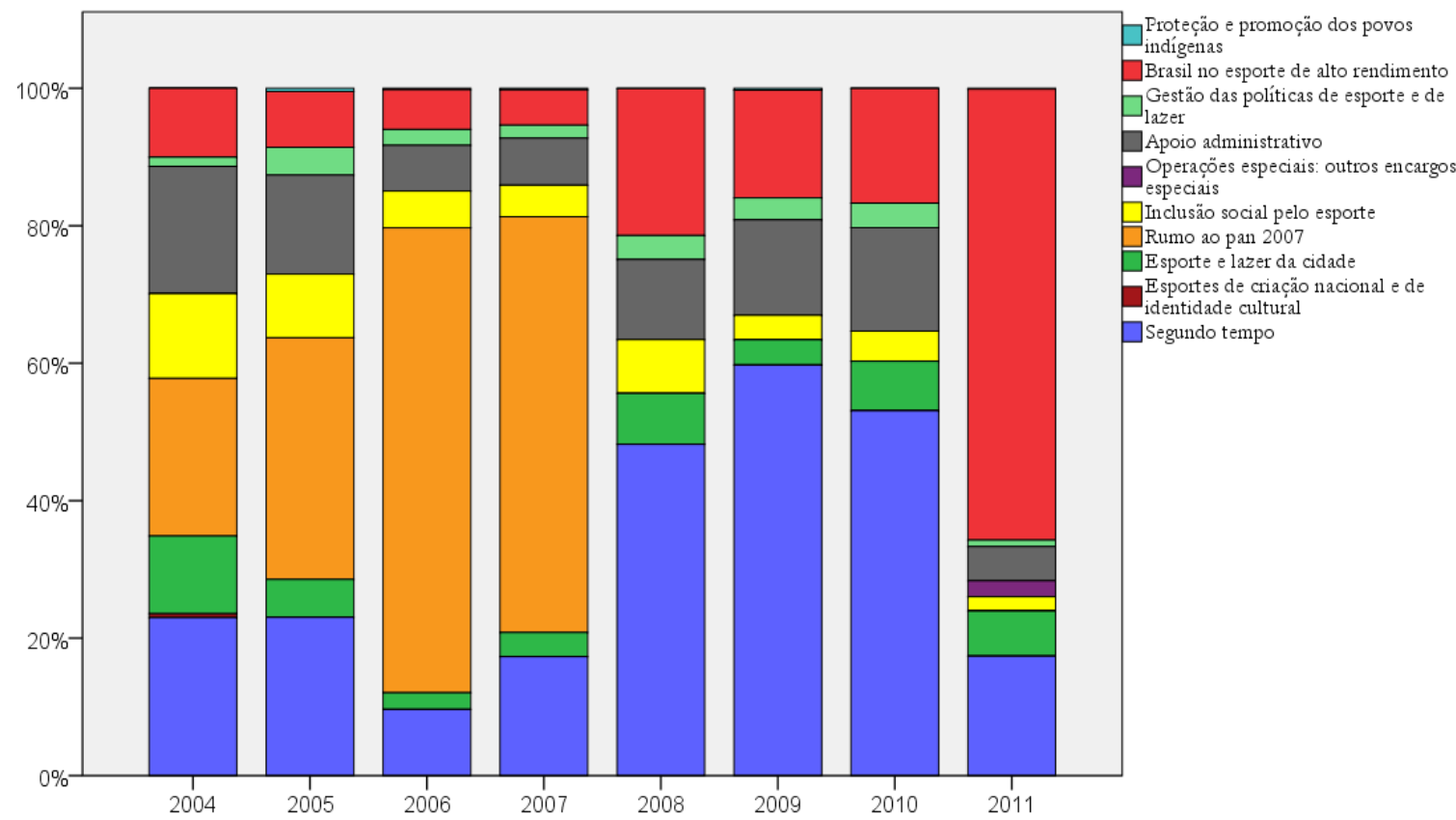

FIGURA1 -Dotações do projeto de Lei Orçamentária Anual (PLOA) da função "Desporto e Lazer" de 2004 a 2011 
O expressivo incremento em 2011 a partir do programa "Brasil no Esporte de Alto Rendimento" esteve, em sua grande parte, ligado a inclusão de quatro ações ${ }^{\text {h }}$ voltadas para a realização da Copa do Mundo da FIFA em 2014 e dos Jogos Olímpicos e Paralímpicos em 2016. Estas ações, que não estavam previstas inicialmente no PPA 2008-2011, totalizaram 51\% ( $\$$ \$ 655,6 milhões) dos recursos no PLOA de 2011 para a função "Desporto e Lazer". Sendo assim, podemos inferir que, a realização dos Jogos Pan e Parapan-Americanos em 2007, a Copa do Mundo da FIFA em 2014 e os Jogos Olímpicos e Paralímpicos em 2016 impactou significativamente a elaboração da proposta orçamentária para a área, promovendo expressivos crescimentos nas dotações orçamentárias designadas pelo Poder Executivo ao ME.

O financiamento de grandes eventos esportivos também impactou na designação do programa prioritário no período. Isto porque, em decorrência do financiamento dos grandes eventos esportivos, as políticas de esporte e lazer do período de 2004-2011 foram marcadas por três enfoques. O primeiro enfoque foi relativo aos anos de 2005, 2006 e 2007, no qual o programa "Rumo ao Pan 2007" totalizou 35,2\%, 67,6\% e 60,5\% dos recursos no PLOA para a área. O segundo enfoque foi relativo aos anos de 2008, 2009 e 2010, no qual o programa "Segundo Tempo" figurou como prioritário na área, somando, respectivamente, $48,2 \%, 59,7 \%$ e $53,1 \%$ dos recursos do PLOA para a área. O terceiro enfoque foi relativo ao ano de 2011, no qual a prioridade se voltou para o programa "Brasil no Esporte de Alto
Rendimento", com 65,6\% dos recursos no PLOA da área. O programa "Esporte e Lazer da Cidade", voltado para a garantia do direito ao esporte de participação, não foi priorizado em nenhum dos anos nesta etapa do processo orçamentário, e em 2006, somou apenas $2,4 \%$ dos recursos no PLOA.

Após a elaboração do PLOA pelo Poder Executivo, a proposta é enviada ao Poder Legislativo para ser apreciado e votado. Neste Poder, o PLOA é encaminhado para a Comissão Mista de Planos, Orçamentos Públicos e Fiscalização (CMPOF) ${ }^{i}$, onde é discutido e pode ser alterado pelos parlamentares por meio de emendas individuais, de bancada, de comissão e/ou de relatoria. As emendas são proposições de alterações textuais ou de despesas. No caso das despesas, estas podem ser de apropriação, remanejamento ou cancelamento de determinados itens (rubricas). Feitas as alterações, o PLOA segue para o plenário do Congresso Nacional onde é votado até o dia 22 de dezembro. Após a aprovação, o PLOA retorna ao Poder Executivo para ser sancionado com ou sem vetos como Lei Orçamentária Anual (LOA).

A proposta orçamentária sancionada como lei apresentou divergências significativas do PLOA elaborado inicialmente pelo Poder Executivo. A primeira diferença esteve relacionada ao montante de recursos designados à função "Desporto e Lazer". Em todos os anos do período, a LOA totalizou um planejamento orçamentário maior do que o que foi proposto pelo PLOA. Ou seja, no decorrer de todos os anos, os parlamentares propuseram incrementos orçamentários na área do esporte e lazer.

TABELA 2 -Dotações da Lei Orçamentária Anual (LOA) da função "Desporto e Lazer" de 2004 a 2011

\begin{tabular}{cccc}
\hline Ano & R\$ LOA & Variação da LOA anterior & Variação PLOA X LOA \\
\hline 2004 & $357.890 .276,00$ & - & $+173,6 \%$ \\
2005 & $631.346 .916,00$ & $+76,4 \%$ & $+270,1 \%$ \\
2006 & $885.977 .751,00$ & $+40,3 \%$ & $+129,2 \%$ \\
2007 & $923.118 .828,00$ & $+4,2 \%$ & $+106,4 \%$ \\
2008 & $1.138 .886 .479,00$ & $+23,4 \%$ & $+300,7 \%$ \\
2009 & $1.397 .683 .667,00$ & $+22,7 \%$ & $+263,4 \%$ \\
2010 & $1.517 .034 .989,00$ & $+8,5 \%$ & $+273,5 \%$ \\
2011 & $2.405 .012 .197,00$ & $+58,5 \%$ & $+87,1 \%$ \\
\hline Total & $\mathbf{9 . 2 5 6 . 9 5 1 . 1 0 3 , 0 0}$ & & $+164,8 \%$ \\
\hline
\end{tabular}

Os acréscimos propostos pelos parlamentares não atingiram os programas governamentais de maneira equitativa e não seguiram as prioridades apontadas pelo Poder Executivo por meio do PLOA. Deste modo, a segunda divergência entre a proposta elaborada pelo Poder Executivo e aquela que foi apreciada pelo Poder Legislativo diz respeito às prioridades e distribuição dos recursos orçamentários na área. 


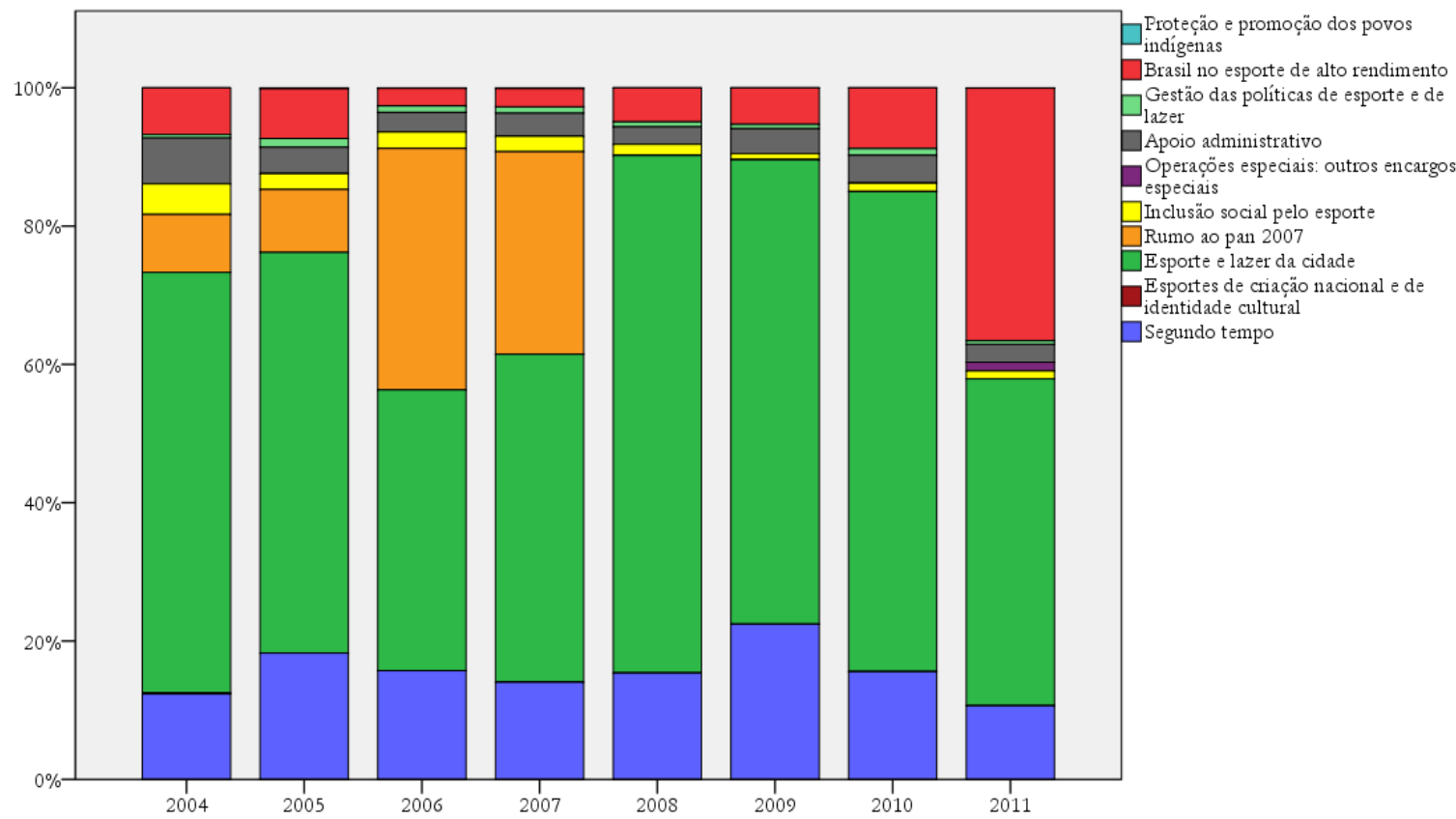

FIGURA 2 -Distribuição das dotações da Lei Orçamentária Anual (LOA) da função "Desporto e Lazer" de 2004 a 2011

Se por um lado as propostas orçamentárias do PLOA não priorizaram um único programa ao longo do período analisado, o PLOA apreciado pelo Poder Legislativo priorizou o programa "Esporte e Lazer da Cidade" no decorrer de todos os anos do período. Este programa, que havia somado um dos menores orçamentos no PLOA do Poder Executivo (5,7\%), passou a totalizar o maior volume de recursos nos dois planos de governos (49,3\% e 61,7\%, respectivamente) e em todas as propostas orçamentárias anuais apreciadas pelo Poder Legislativo.

Diversos autores afirmam que, devido às restrições constitucionais, o volume de recursos que sobra para as emendas é relativamente baixo, o que impede que exista uma redefinição de prioridades por parte do Poder Legislativo na proposta elaborada pelo Poder Executivo ${ }^{18-20}$. Isto, no entanto, não se efetivou no caso do processo de elaboração das políticas federais para o esporte e lazer. Neste caso, as emendas parlamentares foram significativas tanto no volume de recursos quanto na distribuição da programação orçamentária da LOA. Elas representaram 62,2\% (R \$ 5,7 bilhōes) do que foi previsto pela LOA de 2004 a 2011. Em especial, as emendas parlamentares foram essenciais na política para o esporte de participação implementada via programa "Esporte e Lazer da Cidade". Aproximadamente $96,3 \%$ do orçamento do "Esporte e Lazer da Cidade" foi decorrente dos recursos alocados pelos deputados e senadores no processo de planejamento orçamentário. Dos $\mathrm{R} \$$ 5,7 bilhões de incrementos propostos via emendas à função "Desporto e Lazer", aproximadamente $89,6 \%$, foram provenientes dos acréscimos feitos ao "Esporte e Lazer da Cidade". Tal como ressaltado por Castelan ${ }^{12}$ e Matias ${ }^{21}$, o "Esporte e Lazer da Cidade" e, consequentemente, a política federal para o esporte de participação tem se mantido enquanto uma ação governamental em decorrência de emendas parlamantares.

TABELA 3 -Somatório das dotações do Projeto de Lei Orçamentária Anual (PLOA) e da Lei Orçamentária Anual (LOA) da função "Desporto e Lazer" de 2004 a 2011 (valores em R \$ milhões)

\begin{tabular}{cccc}
\hline Programa & R\$ PLOA & R\$ LOA & Variação PLOA x LOA \\
\hline Esporte e Lazer da Cidade & 198,02 & $5.362,57$ & $1.409,09$ \\
Segundo Tempo & 989,91 & $+2.608,1 \%$ & $+42,3 \%$ \\
Brasil no Esporte de Alto Rendimento & $1.104,58$ & $1.257,80$ & $+13,9 \%$ \\
Rumo ao Pan 2007 & 622,00 & 667,35 & $+7,3 \%$ \\
\hline
\end{tabular}


continuação

\begin{tabular}{cccc}
\hline Programa & R\$ PLOA & R\$ LOA & Variação PLOA x LOA \\
\hline Apoio Administrativo & 316,76 & 306,62 & $-3,2 \%$ \\
Inclusão Social pelo Esporte & 153,71 & 147,86 & $-3,8 \%$ \\
Gestão das Políticas de Esporte e de Lazer & 74,62 & 70,50 & $-5,5 \%$ \\
Operações Especiais: outros encargos & 30,00 & 30,00 & $0,0 \%$ \\
especiais & 5,30 & 4,40 & $-17,0 \%$ \\
Proteção e Promoção dos Povos Indígenas & 0,75 & 0,75 & $0,0 \%$ \\
Esportes de Criação Nacional e de Identidade & Cultural & $\mathbf{3 . 4 9 5 , 6 5}$ & $\mathbf{+ 1 6 4 , 8 \%}$ \\
\hline Total &
\end{tabular}

Apesar das alteraçóes efetuadas pelos parlamentares promoverem uma reconfiguração no PLOA elaborado pelo Poder Executivo, o mesmo aprovou todas as propostas de 2004 a 2011 sem vetos expressivos. Pelo menos dois fatores podem estar relacionados à referida anuência do Poder Executivo. $\mathrm{O}$ primeiro deles está relacionado ao entendimento de que estas alterações se comportam de maneira complementar e não contrária ao PLOA elaborado pelo Poder Executivo. Isto porque, ainda que os parlamentares tenham dotaçóes asseguradas e fixadas, a estrutura do orçamento define quais os programas e açõos passíveis de receberem recursos. Estes, portanto, não expressam suas preferências sem restriçôes ${ }^{22}$.

A participação do Poder Legislativo como uma forma de complementação do orçamento para o esporte e lazer não é uma prática velada. Esta prática é aparentemente esperada pelo Poder Executivo, conforme pode se observar em documentos do processo orçamentário. De acordo com o Relatório Setorial do PLOA 2004, o significativo aporte de recursos via emendas parlamentares ao $\mathrm{ME}$, evidenciou, "que o Poder Executivo deixa a cargo do Congresso Nacional o complemento de parte das programaçóes" (p. 4-5) ${ }^{23}$. $\mathrm{Na}$ espera pela complementação, é possível verificar ainda a existência de orientaçôes relativas à apresentação de emendas por parte dos parlamentares. Para a LOA de 2005, por exemplo, constava no Manual de Emendasi que as emendas relativas à implantação de infraestrutura nas escolas públicas contariam com prioridade. De acordo com este documento, por meio de audiências realizadas no Congresso Nacional, o Ministro do Esporte afirmou que um dos objetivos principais do ME em 2005 seria o de, "dotar as escolas públicas de infraestrutura necessária à prática desportiva, e que emendas que tenham esse objetivo receberão tratamento prioritário" (p. 87) ${ }^{25}$.

Além de orientações formais, na espera de complementações orçamentárias o ME também recorreu a articulações com parlamentares. Estas articulações foram até mesmo citadas pelos relatórios do ME. De acordo com o Relatório de Avaliação Anual de 2005, a gerência do programa "Esporte e Lazer da Cidade" buscou, por meio de articulações com o Congresso Nacional, orientar a apresentação de emendas parlamentares ao funcionamento de Núcleos de Esporte Recreativo e Lazer e ao funcionamento de Núcleos de Desenvolvimento do Esporte Recreativo e Lazer (Rede Cedes) ${ }^{26}$. Estas articulações também foram verificadas por STAREPRAVO ${ }^{27}$. De acordo com o autor, diante do baixo orçamento do "Esporte e Lazer da Cidade", a gerência do programa buscou atuar politicamente junto ao parlamento a fim de angariar recursos para o programa ${ }^{27}$.

A articulação junto ao Congresso Nacional não se restringiu ao programa "Esporte e Lazer da Cidade". De acordo com o relatório do ME, no exercício financeiro de 2008, o programa "Segundo Tempo" buscou ampliar o seu orçamento por meio de articulações com parlamentares que visavam a aprovação de emendas individuais e de bancadas para o programa ${ }^{28}$.

O segundo fator para a anuência do Poder Executivo frente à reconfiguração da programação orçamentária na função "Desporto e Lazer" se refere ao caráter autorizativo do orçamento público brasileiro. Apesar de o orçamento público ser uma lei, o Poder Executivo, com exceção das despesas obrigatórias, não tem obrigatoriedade na execução das despesas. Neste sentido, tal como destacado por SouZA ${ }^{29}$, "vetar emendas pode ser um desgaste antecipado para o presidente, já que o orçamento é uma peça indicativa e não compulsória de gasto" (p. 356). Além da não obrigatoriedade, o Poder Executivo ainda dispóe de mecanismos retificadores das propostas - créditos adicionais e/ou cortes 
orçamentários -, que possibilitam ao mesmo fazer ajustes na proposta sancionada como lei. Tal como veremos a seguir, tanto a proposição de alterações na LOA quanto a execução parcial do orçamento foram mecanismos utilizados pelo Poder Executivo no decorrer do processo de execução da proposta orçamentária da função "Desporto e Lazer".

\section{Execução orçamentária da função "Desporto e Lazer"}

Após a sanção da proposta orçamentária como LOA e o início do exercício financeiro, o processo de execução da LOA acontece em três etapas: empenho, liquidação e pagamento. Esta execução, no entanto, depende da liberação de cotas orçamentárias por parte do Poder Executivo. Além disso, a programação orçamentária proposta pela
LOA pode sofrer ajustes por meio da abertura de créditos adicionais por parte do Poder Executivo. Sendo assim, a fim de apreender o montante que foi de fato previsto para a função "Desporto e Lazer", vale considerar o montante de recursos autorizados no decorrer do período.

As propostas sancionadas como LOA para a área de 2004 a 2011 apresentaram mudanças em termos de volume e de distribuição de recursos. Em todos os anos do período analisado, as propostas autorizadas totalizaram incrementos à LOA, sendo que estes ocorreram de maneira mais expressiva em 2007 em decorrência dos créditos adicionais propostos ao "Rumo ao Pan 2007". O volume de recursos autorizados na função "Desporto e Lazer" totalizou $\mathrm{R} \$ 11,3$ bilhões, o que correspondeu à um incremento por parte do Poder Executivo de 22,2\% dos recursos previstos pela LOA.

TABELA 4 -Dotações autorizadas da função "Desporto e Lazer" de 2004 a 2011

\begin{tabular}{cccc}
\hline Ano & R\$ Autorizado & Variação do Autorizado anterior & Variação LOA X Autorizado \\
\hline 2004 & $383.716 .805,00$ & - & $+7,2 \%$ \\
2005 & $685.109 .961,00$ & $+78,5 \%$ & $+8,5 \%$ \\
2006 & $1.018 .997 .605,00$ & $+48,7 \%$ & $+15,0 \%$ \\
2007 & $1.575 .555 .828,00$ & $+54,6 \%$ & $+70,7 \%$ \\
2008 & $1.392 .795 .119,00$ & $-11,6 \%$ & $+22,3 \%$ \\
2009 & $1.463 .976 .971,00$ & $+5,1 \%$ & $+4,7 \%$ \\
2010 & $2.077 .487 .942,00$ & $+41,9 \%$ & $+36,9 \%$ \\
2011 & $2.715 .914 .832,00$ & $+30,7 \%$ & $+12,9 \%$ \\
\hline Total & $\mathbf{1 1 . 3 1 3 . 5 5 5 . 0 6 3 , 0 0}$ & & $+\mathbf{2 2 , 2} \%$ \\
\hline
\end{tabular}

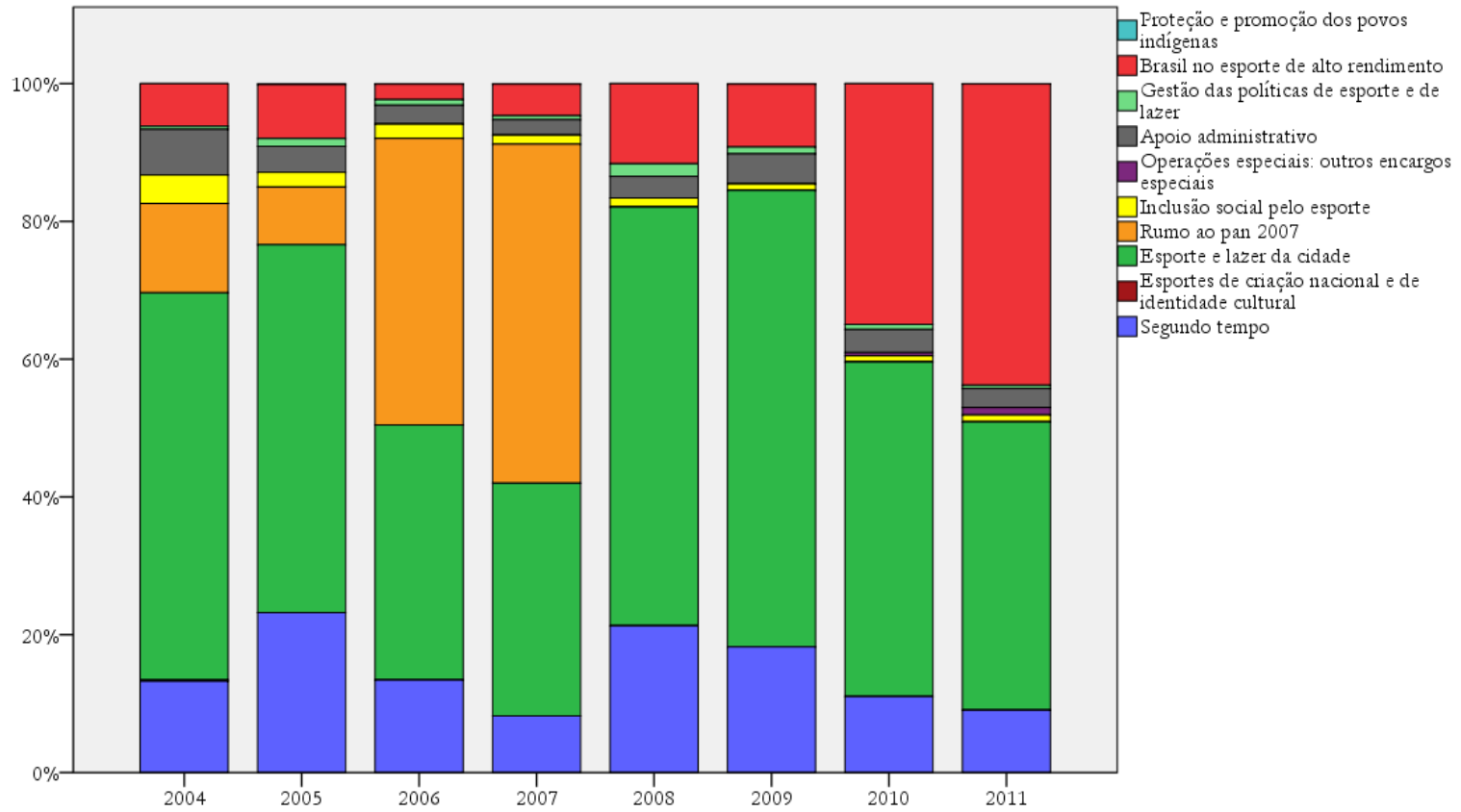

FIGURA 3 -Distribuição das dotações autorizadas da função "Desporto e Lazer" de 2004 a 2011 
Apesar do incremento no montante total, as proposições de alterações à LOA da função "Desporto e Lazer" envolveram tanto a abertura de créditos adicionais - suplementares, especiais e extraordinários -, quanto a promoção de cancelamentos de dotaçóes na LOA. No que se referiu aos créditos adicionais, aproximadamente $85,7 \%$ do volume adicional proposto nesta etapa foi designado aos programas do esporte de rendimento: "Brasil no Esporte de Alto Rendimento" e "Rumo ao Pan 2007”. Estes programas totalizaram, respectivamente, $89,3 \%$ e $95,7 \%$ de incrementos dos recursos da LOA. Programas como "Esporte e Lazer da Cidade" e "Segundo Tempo", por exemplo, totalizaram nesta etapa do processo orçamentário acréscimos de 1,7\% e 7,5\%, respectivamente.

Ainda em relação aos créditos adicionais, vale destacar o expressivo e recorrente uso dos créditos extraordinários por parte do Poder Executivo em 2007. A fim de garantir a realização dos Jogos Pan e Parapan-americanos de 2007, o Poder Executivo adicionou à proposta orçamentária do programa "Rumo ao Pan 2007" em 2007 R\$ 591 milhões por meio de créditos extraordinários. Vale destacar que, de acordo com a Lei $\mathrm{n}^{\circ} \cdot 4.320^{30}$, a utilização de créditos extraordinários ocorre não devido a falhas na estimativa inicial de gastos (casos em que se usaria o crédito suplementar), e nem devido a falhas de planejamento (casos em que se usaria o crédito especial), mas em decorrência de eventos extraordinários e imprevisíveis. Deste modo, tal como destacado por Silva ${ }^{31}$, a característica que suporta a abertura de créditos extraordinários é a ocorrência de eventos em que não houve a mínima possibilidade de antevê-los. Esta característica, contudo, não se adequa aos Jogos Pan e Parapanamericanos de 2007. A realidade foi que, conforme relatado por Whitson e Horne ${ }^{32}$, os gastos com os grandes eventos esportivos tendem a ser subestimados. Isto claramente aconteceu no Brasil.

No que se referiu aos cancelamentos, apesar de nenhum programa totalizar decréscimos no somatório do período, os programas "Esporte e Lazer da Cidade", "Segundo Tempo", "Brasil no Esporte de Alto Rendimento" e "Gestão das Políticas de Esporte e Lazer" sofreram cancelamentos de dotações por parte do Poder Executivo em algum dos anos do período. Em 2009, por exemplo, o programa "Segundo Tempo" teve um cancelamento de $\mathrm{R}$ \$ 46,9 milhóes e em 2010 o programa "Esporte e Lazer" totalizou um corte de R \$ 44,3 milhões previstos pela LOA.

O "Esporte e Lazer da Cidade" se manteve enquanto o programa com maior volume de recursos autorizados se considerado o período analisado como um todo ( $\mathrm{R}$ \$ 5,4 bilhões - 48,2\%), seguido do "Brasil no Esporte de Alto Rendimento" ( $\mathrm{R}$ \$ 2,3 bilhões $-21 \%)$, "Segundo Tempo" ( $\mathrm{R}$ \$ 1,5 bilhōes - 13,4\%) e "Rumo ao Pan 2007" (R \$ 1,3 bilhões - 11,5\%). A priorização orçamentária no decorrer de alguns anos em específico, contudo, seguiu a tendência do PLOA elaborado pelo Poder Executivo. Em decorrência das alterações propostas pelo Poder Executivo, em 2006 e 2007 o "Rumo ao Pan 2007" e em 2011 o "Brasil no Esporte de Alto Rendimento" somaram o maior volume de recursos autorizados.

Concomitante à autorização de recursos, o processo de execução orçamentária seguiu com o empenho e liquidação das despesas autorizadas. A função "Desporto e Lazer" liquidou $\mathrm{R} \$$ 6,9 bilhões, o que correspondeu a $61,7 \%$ do total que foi autorizado para a área. Ou seja, 28,3\% dos recursos que foram planejados não foram empenhados e liquidados e, consequentemente, não foram executados.

TABELA 5-Dotações liquidadas da função "Desporto e Lazer" de 2004 a 2011

\begin{tabular}{cccc}
\hline Ano & $\mathbf{R}$ Liquidado & Variação do Liquidado anterior & Liquidação \\
\hline 2004 & $271.419 .136,42$ & - & $70,7 \%$ \\
2005 & $423.069 .816,00$ & $+55,9 \%$ & $61,8 \%$ \\
2006 & $737.740 .827,09$ & $+74,4 \%$ & $72,4 \%$ \\
2007 & $1.414 .742 .929,54$ & $+91,8 \%$ & $89,8 \%$ \\
2008 & $963.810 .870,05$ & $-31,9 \%$ & $69,2 \%$ \\
2009 & $982.220 .417,07$ & $+1,9 \%$ & $67,1 \%$ \\
2010 & $1.036 .279 .595,09$ & $+5,5 \%$ & $49,9 \%$ \\
2011 & $1.152 .796 .355,54$ & $+11,2 \%$ & $42,4 \%$ \\
\hline Total & $\mathbf{6 . 9 8 2 . 0 7 9 . 9 4 6 , 8 0}$ & & $\mathbf{6 1 , 7 \%}$ \\
\hline
\end{tabular}




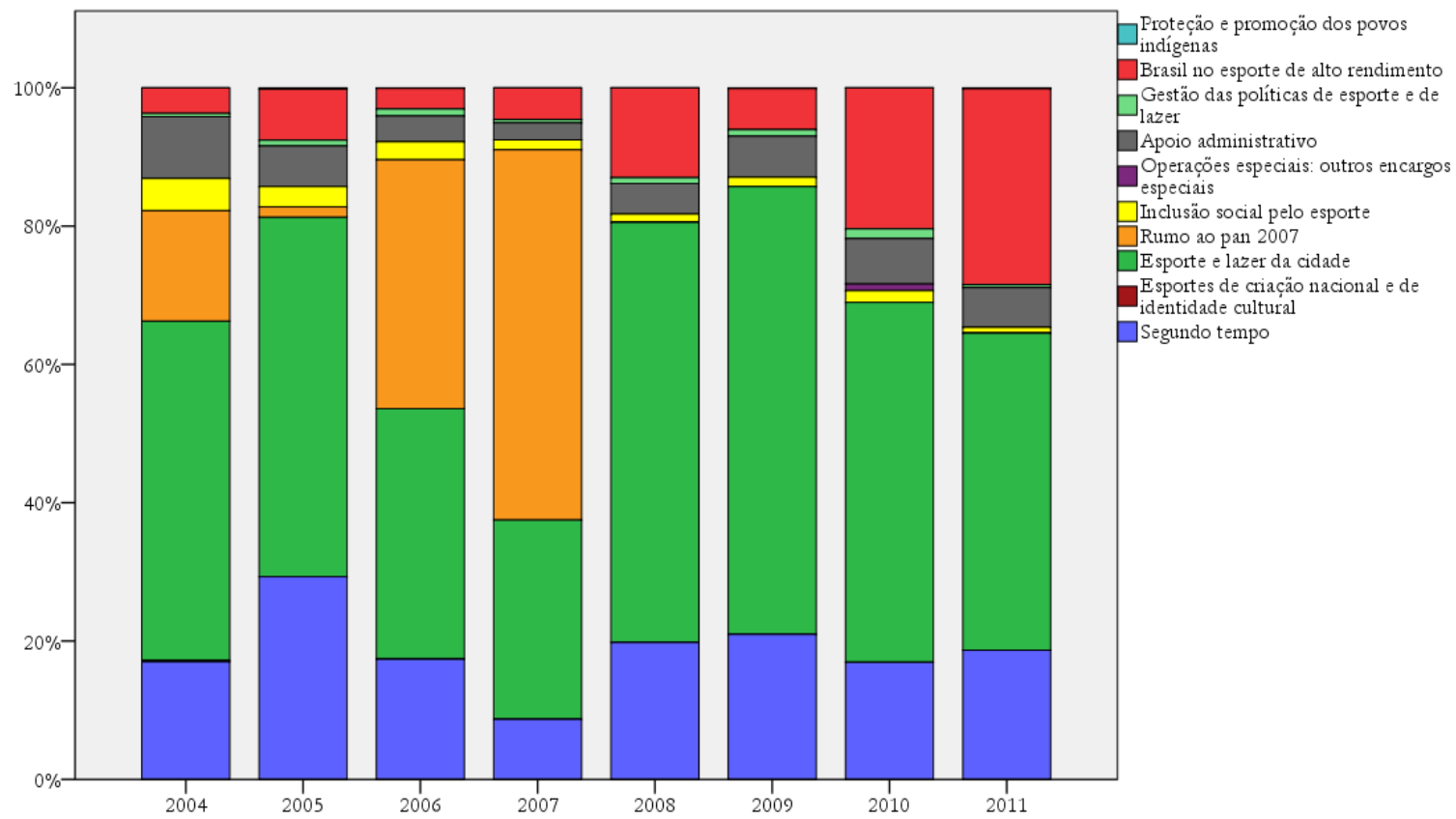

FIGURA 4 -Distribuição das dotações liquidadas da função "Desporto e Lazer" de 2004 a 2011

A não liquidação de todos os recursos autorizados não é exclusividade da função "Desporto e Lazer" e a discrepância entre o volume de recursos previstos e o volume de recursos executados já foi verificada em outros trabalhos ${ }^{6,8,10,11}$. Conforme exposto anteriormente, o processo de empenho e liquidação depende da liberação das cotas orçamentárias por parte do Poder Executivo. Este processo, por sua vez, depende do alcance das metas anuais em relação à arrecadação de receitas, realização de despesas e pagamento da dívida pública, bem como à discricionariedade do Poder Executivo frente à execução das despesas previstas.

De acordo com diversos relatórios do $\mathrm{ME}$, no decorrer do período analisado, a não execução da totalidade das dotações autorizadas, ou seja, a divergência entre o que foi autorizado e o que foi liquidado ocorreu, "devido à insuficiência de limite orçamentário" 33 . Ainda de acordo com estes documentos, aproximadamente $99 \%$ do total do limite autorizado que foram disponibilizados, foram executados ${ }^{33-39}$. Ou seja, o baixo percentual de liquidação esteve diretamente relacionado com a programação orçamentária e financeira instituída pelo Poder Executivo e não com a capacidade exclusiva de liquidação da gerência do ME. Deste modo, ainda que atrasos na aprovação do orçamento e o período impeditivo eleitoral tenham sido apontados como prejudiciais à execução orçamentária na área ${ }^{40}$, o baixo percentual de execução orçamentária na área foi resultado de dotações do ME contingenciadas pelo Poder Executivo.

O impacto do contingenciamento nas despesas da função "Desporto e Lazer" já foi destacado por outros autores ${ }^{8,10,41}$. Tal como destacado por Starepravo, Mezzadri e Marchi Júnior ${ }^{42}$, este quadro revela "um histórico político no Brasil que privilegia a área econômica em detrimento a área social, e que dentro da área social estabelece uma hierarquia de prioridades na qual o esporte ocupa normalmente uma das últimas posições" (p. 219).

Um dos motivos para a área ter sido afetada de maneira expressiva pelo contingenciamento de recursos pode estar relacionado com o fato de que a função "Desporto e Lazer" foi composta por um baixo teor de receitas vinculadas e de despesas obrigatórias. Conforme destacado anteriormente, o Poder Executivo, com exceção das despesas obrigatórias, não está obrigado a executar aquilo que foi previsto pela LOA. Se for conveniente ao Poder Executivo, este, portanto, pode optar por não executar as despesas discricionárias, ou seja, ele não precisa executar quase que a totalidade dos recursos orçamentários da área do esporte e lazer.

A não obrigatoriedade na execução orçamentária está relacionada ao caráter autorizativo da LOA. Este caráter autorizativo, tal como destacado por VERONEZ ${ }^{8}$ é prejudicial às políticas públicas em áreas que não possuem receitas vinculadas, como é o caso do esporte e lazer. Esta noção é corroborada por 
Athayde, Mascarenhas e Salvador ${ }^{11}$ ao afirmar que a baixa execução orçamentária das políticas de esporte e lazer é impactada pela inexistência de recursos e gastos de natureza obrigatória. Ainda de acordo com os autores, diferentemente do que ocorre nas áreas da saúde, educação e assistência social, a área do esporte e lazer não somente não possui obrigatoriedade quanto a um percentual de execução mínima, mas também não tem um percentual mínimo vinculado ao Produto Interno Bruto (PIB $)^{11}$. Os recorrentes contingenciamentos decorrentes da programação orçamentária, portanto, afetaram, bem como tendem a continuar afetando, de maneira significativa, a programação orçamentária das políticas federais para o esporte e lazer.

A proposição de vinculação de receitas na área do esporte e lazer tem sido debatida e reivindicada por profissionais e gestores destas áreas. Este assunto se fez presente nas três conferências nacionais de esporte. Na I CNE, em 2004, houve a proposição de que tanto os órgãos municipais quanto estaduais de esporte e lazer fossem instituídos como unidades orçamentárias e que os mesmos fossem dotados de no mínimo $1 \%$ dos respectivos orçamentos municipais e estaduais $^{43}$. Na II CNE, em 2006, foi proposto a criação de uma emenda constitucional para a vinculação e destinação de um percentual mínimo - $1 \%$ da receita tributária -, nos três níveis de governo (federal, estadual e municipal) para o desenvolvimento das políticas de esporte e lazer ${ }^{44}$. $\mathrm{Na}$ terceira e última CNE, em 2010, a criação de uma emenda constitucional foi novamente citada. O percentual, contudo, passou para no mínimo 2\% do orçamento da União, 1,5\% dos orçamentos dos estados e Distrito Federal e 1\% dos municípios ${ }^{42}$.

Apesar das proposições, a vinculação de receitas não foi regulamentada. A única regulamentação existente hoje que se refere à vinculação de receitas encontra-se disposta nos $\$ 2^{\circ}$ e $\$ 3^{\circ}$ do art. 6 da Lei $n^{\circ} .9 .615$ de 1998. De acordo com a legislação, dentre os recursos que constituem o $\mathrm{ME}$, um terço do disposto no $\$ 2^{\circ}$, o qual trata do adicional de 4,5\% incidente de cada bilhete de concursos de prognósticos, "será repassado às Secretarias de Esporte dos Estados e do Distrito Federal ou, na inexistência destas, a órgãos que tenham atribuições semelhantes na área do esporte, proporcionalmente ao montante das apostas efetuadas em cada unidade da Federação", o qual deverá ser aplicado prioritariamente em jogos escolares de esportes olímpicos e paraolímpicos e demais destinaçôes previstas aos recursos do $\mathrm{ME}^{2}$. Ainda de acordo com a legislação, a parcela repassada aos Estados e Distrito Federal deverá ser "aplicada integralmente em atividades finalísticas do esporte, sendo pelo menos 50\% (cinquenta por cento) investidos em projetos apresentados pelos Municípios ou, na falta de projetos, em ações governamentais em benefício dos Municípios"2.

Uma das regulamentaçôes que poderá efetivar mudanças na execução das despesas na área do esporte e lazer é a Emenda Constitucional nº 86. Promulgada em 17 de março de 2015, esta emenda prevê a execução obrigatória de parte de emendas parlamentares individuais do orçamento da união $^{46}$. Visto que a função "Desporto e Lazer" tem grande concentração de emendas e, especialmente, de emendas individuais, esta regulamentação poderá trazer mudanças no financiamento da área. O impacto desta regulamentação no financiamento na área do esporte e lazer poderá ser objeto de futuras pesquisas.

Além do alto teor de despesas discricionárias na área do esporte e lazer e a baixa porção de receitas vinculadas, outro fator que pode ter impactado negativamente o financiamento das políticas de esporte e lazer é que nenhum ente federativo, nem mesmo a União, encontra-se obrigado a promover o acesso ao esporte e lazer como direitos da sociedade brasileira. Ou seja, nenhum órgão governamental encontra-se obrigado a implementar políticas na área do esporte e lazer. Ainda que a legislação brasileira autorize qualquer ente federativo a implementar políticas na área do esporte e lazer, esta legislação não obriga constitucionalmente nenhum ente a implementar políticas nesta área $^{47-49}$. Ou seja, ao mesmo tempo em que o dispositivo constitucional afirma o dever do Estado no fomento ao esporte, este não esclarece quais os níveis e graus de atuação dos diferentes órgãos estatais que têm a obrigação de fomentar o mesmo ${ }^{5,47-51}$.

Além do aspecto econômico inerente ao processo de contingenciamento de recursos, outro aspecto que pode ter impactado a execução orçamentária dos recursos na área do esporte e lazer durante o período analisado diz respeito ao aspecto político na liberação de verbas por parte do Poder Executivo. De acordo com diversos autores, o processo de contingenciamento e liberação de recursos está associado a acordos políticos estabelecidos entre atores do Poder Executivo e Legislativo ${ }^{12,19,52}$. De 
acordo com esta linha de pensamento, ao segurar a execução das despesas previstas pela LOA, o Poder Executivo ao mesmo tempo em que busca cumprir metas fiscais, também negocia a liberação de recursos a partir do apoio político obtido no Congresso Nacional ${ }^{52}$. A execução das emendas e, mais especificamente, das emendas individuais funcionaria, portanto, como uma "moeda de troca" entre parlamentares e o Executivo ${ }^{22}$. Nesta lógica, "o presidente da República recompensa os parlamentares que sistematicamente votam a favor dos projetos de interesse do governo, autorizando a execução de suas emendas individuais, e, ao mesmo tempo, pune os que não votam nesses projetos simplesmente não executando as emendas propostas por eles" (p. 274) ${ }^{19}$.

O entendimento acima, contudo, não é unânime na literatura. De acordo com LiMONGI e Figueiredo 22 , "emendas são executadas sem que os votos esperados sejam dados, e votos são dados sem que a contrapartida - ou seja, a liberação de recursos - ocorra" (p. 740). Para os autores, as variações nas taxas anuais de execução são melhor compreendidas como resposta a condicionantes de caráter econômico do que a oscilaçôes nas bases de apoio do governo ${ }^{22}$.

Diante da impossibilidade de inferir que a execução orçamentária das políticas federais para o esporte e lazer foi mais impactada por aspectos econômicos do que políticos, e sem descartar a influência de ambos os aspectos, a realidade é que a função "Desporto e Lazer" foi fortemente impactada pelo contingenciamento de recursos. Quando liberadas as verbas orçamentárias, estas se deram de maneira descontinuada e concentrada no segundo semestre do exercício financeiro. Esta realidade também foi relatada em períodos anteriores. De acordo com Veronez ${ }^{8}$, em 1995, os recursos previstos começaram a ser liberados somente a partir do mês de junho e, a maior parte deles, foi liberada apenas no mês de dezembro.

O descolamento entre planejamento e execução é reconhecido pelo próprio $\mathrm{ME}$. Ao mesmo tempo em que o referido Ministério reconhece que é necessário que a liberação de recursos esteja em concordância com o efetivo recolhimento das receitas previstas, o mesmo também afirma que é evidente que a não liberação de recursos acarreta uma redução no ritmo dos projetos e atividades, prejudicando, assim, um bom andamento físico e financeiro das ações ${ }^{53}$. Para o ME, este desarranjo entre plano e orçamento se constitui em um problema que precisa ser futuramente equacionado ${ }^{53}$. Este problema não apresentou melhoras na função "Desporto e Lazer" no decorrer do período que analisamos. Ao contrário, ele se acentuou, haja visto os baixos percentuais de execução orçamentária do segundo PPA (20082011).

Sendo assim, se por um lado o fato do orçamento ser autorizativo e os corriqueiros contingenciamentos têm o propósito de assegurar a efetiva capacidade financeira do Poder Público, por outro lado, esta característica e o uso deste mecanismo têm comprometido os processos de planejamento e execução de políticas públicas de esporte e lazer. Considerando-se que o orçamento deve estar em sintonia com o planejamento, a previsão de ações implica em adequar o orçamento à política fiscal, de modo que o contingenciamento de recursos não precise ocorrer ou este somente ocorra em casos extremos, "sob pena de demonstrar a total incapacidade dos órgãos públicos em estabelecer uma efetiva política de planejamento" (p. 227) $)^{14}$.

A baixa e irregular execução orçamentária também se fez presente entre os programas governamentais propostos na função "Desporto e Lazer”. Vale destacar que, após a liberação de recursos orçamentários pelo Poder Executivo ao $\mathrm{ME}$, a distribuição dos recursos orçamentários entre os programas e ações previstas pela LOA passou a ser ditada pela gerência deste Ministério. Este, ao receber a cota orçamentária passou a ter sob sua responsabilidade a execução das políticas federais para o esporte e lazer e, diante da pouca porção composta por despesas obrigatórias e vinculadas, dispôs de grande discricionariedade sobre a execução das políticas previstas.

Ao considerarmos, portanto, o percentual de liquidação dos recursos autorizados pelo $\mathrm{ME}$, não identificamos um padrão quanto a execução dos programas governamentais. Isto é, a execução orçamentária na função "Desporto e Lazer" não seguiu a lógica de priorização de um único programa em detrimento de outros. Com exceção dos programas "Esportes de Criação Nacional e de Identidade Cultural", executado apenas em 2004, e "Apoio Administrativo", todos os demais programas da área apresentaram variaçōes no seu percentual de liquidação. $\mathrm{O}$ "Rumo ao Pan 2007”, por exemplo, executou $11,2 \%$ dos recursos autorizados em 2005, e em 2007 executou 97,7\%. 
TABELA 6 -Dotações autorizadas e liquidadas da função "Desporto e Lazer" de 2004 a 2011 (valores em R \$ milhões)

\begin{tabular}{cccc}
\hline Programa & R\$ Autorizado & R\$ Liquidado & Liquidação \\
\hline Esporte e Lazer da Cidade & $5.453,61$ & $3.316,91$ & $60,8 \%$ \\
Segundo Tempo & $1.514,67$ & $1.208,48$ & $79,8 \%$ \\
Rumo ao Pan 2007 & $1.306,41$ & $1.073,02$ & $82,1 \%$ \\
Brasil no Esporte de Alto Rendimento & $2.381,94$ & 849,48 & $35,7 \%$ \\
Apoio Administrativo & 366,14 & 346,64 & $94,7 \%$ \\
Inclusão Social pelo Esporte & 149,40 & 116,83 & $78,2 \%$ \\
Gestão das Políticas de Esporte e de Lazer & 95,25 & 56,13 & $58,9 \%$ \\
Operações Especiais: outros encargos especiais & 40,00 & 10,00 & $25,0 \%$ \\
Proteção e Promoção dos Povos Indígenas & 5,38 & 4,03 & $74,9 \%$ \\
Esportes de Criação Nacional e de Identidade Cultural & 0,75 & 0,55 & $73,3 \%$ \\
\hline Total & $\mathbf{1 1 . 3 1 3 , 5 6}$ & $\mathbf{6 . 9 8 2 , 0 8}$ & $\mathbf{6 1 , 7 \%}$ \\
\hline
\end{tabular}

Os nossos dados também indicaram que nenhum programa governamental implementado na função "Desporto e Lazer" apresentou uma tendência crescente de investimentos no decorrer do período analisado. Ou seja, todos os programas propostos apresentaram períodos de decréscimos em suas dotaçóes liquidadas. Enquanto políticas públicas, seria de se esperar que o financiamento dos programas governamentais mantivesse uma tendência média crescente no decorrer dos anos, o que na realidade não aconteceu.

No somatório do período, o "Esporte e Lazer da Cidade" se manteve como o programa com maior volume de recursos liquidados ( $\mathrm{R} \$ 3,3$ bilhōes - 47,5\%), seguido do "Segundo Tempo" (R\$ 1,2 bilhões - 17,3\%), "Rumo ao Pan 2007" (R\$ 1 bilhão - 15,4\%) e "Brasil no Esporte de Alto Rendimento" (R\$ 849 milhões - 12,2\%). O programa "Esporte e Lazer da Cidade" contou com predominância orçamentária em todos os anos do período analisado, exceto pelo ano de 2007 . Neste ano, os recursos liquidados seguiram a tendência dos recursos autorizados, e o programa "Rumo ao Pan 2007" somou o maior volume de recursos da função "Desporto e Lazer".

A falta de regularidade na liquidação de recursos, bem como a inexistência de um padrão no financiamento para a área que tenha perpassado as diferentes etapas do processo orçamentário revela que o governo federal não teve, durante o período analisado, uma política clara para o setor esportivo. Isto é, aos considerarmos a evolução dos investimentos no decorrer dos anos e das etapas do ciclo orçamentário brasileiro, concluímos que não houve uma priorização única e exclusiva de ações no financiamento das políticas federais para o esporte e lazer. Sendo assim, os achados desta pesquisa contrariam a assertiva de vários autores ${ }^{3-8}$ que, no financiamento orçamentário, os programas para o esporte de alto rendimento e/ou os megaeventos esportivos contaram com privilégio orçamentário.

Dentre as possíveis razōes para as divergências entre os resultados de nosso estudo e dos citados anteriormente, destacamos as diferenças quanto ao recorte temporal considerado, as etapas do processo orçamentário analisadas, e o agrupamento de programas/ações efetuados pelos autores.

Exceto pelo trabalho de CASTRO et al. ${ }^{6}$, nenhum dos estudos citados abordou o período de 2004 a 2011. Nenhum destes trabalhos também se propôs a investigar o financiamento das políticas federais para o esporte e lazer no decorrer dos processos de elaboração e execução orçamentária. Muitos destes, inclusive, não especificaram a que etapa do ciclo orçamentário as suas conclusões se remetem. Comum a várias destas pesquisas é a opção de agrupar as dotações orçamentárias dos programas "Rumo ao Pan 2007" e "Brasil no Esporte de Alto Rendimento".

Tendo em vista que as opções metodológicas quanto aos recortes temporais, organização dos dados e etapas orçamentárias consideradas são elementos essenciais nos trabalhos acerca do orçamento público, gostaríamos de esclarecer algumas questōes quanto as opções efetuadas neste trabalho. A primeira delas se refere à noção de prioridade no orçamento público brasileiro. Em nosso estudo, buscamos pautar nossas conclusóes acerca das prioridades das políticas federais para o esporte e lazer não somente a partir da consideração do predomínio orçamentário de um determinando programa governamental. Isto é, além de considerar o volume de recursos designado aos programas governamentais, buscamos considerar a sua perenidade orçamentária no decorrer dos anos 
e no decorrer das etapas do ciclo orçamentário, bem como a existência, ou não, de padrões no financiamento destes no decorrer de todos as etapas do ciclo orçamentário. Tendo em vista estes aspectos é que concluímos que o financiamento orçamentário para as políticas federais para o esporte e lazer não apresentou um quadro prioritário único.

Outro aspecto que gostaríamos de destacar é que, ainda que entendamos que a realização de grandes eventos esportivos esteja atrelada à dimensão do esporte de alto rendimento, não compreendemos o financiamento destes eventos como uma política para o desenvolvimento do esporte de rendimento. Corroboramos com a assertiva de AlmeIDA ${ }^{54}$, que a presença dos grandes eventos esportivos, "no governo justifica tornar a questão pública, mas num sentido político que náo deveria ser trazido em conjunto como uma questão da política pública para o esporte" (p. 189). Deste modo, o privilégio orçamentário dado ao "Rumo ao Pan 2007" em 2007, bem como no somatório do PPA 2004-2007, nos impossibilita afirmar que o financiamento orçamentário das políticas federais para o esporte e lazer privilegiou o esporte de alto rendimento frente às demais manifestaçóes esportivas. O que podemos afirmar é que, no período analisado, houve um direcionamento de um grande volume de recursos orçamentários para a realização de grandes eventos esportivos no país. Este direcionamento, no entanto, não esteve diretamente atrelado a aumentos expressivos nas açóes relativas ao desenvolvimento do esporte de rendimento no país. Estes investimentos se deram prioritariamente a partir do Poder Executivo e em períodos específicos do recorte temporal analisado.

Ao mesmo tempo em que concluímos que não houve predomínio orçamentário do esporte de rendimento no período analisado, não descartamos a possibilidade de que esta manifestação esportiva não tenha passado a ser privilegiada a partir do ano final do recorte temporal da nossa pesquisa, haja visto algumas proposiçóes que se efetivaram no período final do recorte aqui proposto. Em 2010, a III Conferência Nacional do Esporte teve como propósito a elaboração de um Plano Decenal do Esporte e Lazer com o intuito de projetar o Brasil entre as dez potências esportivas do mundo. Em junho de 2011, houve uma reestruturação do ME. A partir desta reestruturação, a SNDEL e SNEE passaram a integrar uma mesma pasta ministerial Secretaria Nacional de Esporte, Educação, Lazer e Inclusão Social (SNEELIS) - e houve a criação da Secretaria Nacional de Futebol e Defesa dos Direitos do Torcedor. Já a Secretaria Nacional do Esporte de Alto Rendimento permaneceu intacta. Ainda em 2011, o governo federal elaborou o PPA 2012-2015, e as ações do ME passaram a estar congregadas no programa temático intitulado "Esporte e Grandes Eventos Esportivos". Ao contrário das assertivas de que as dotaçôes do "Esporte e Lazer da Cidade" e "Segundo Tempo" tenham sido zeradas",10, as dotaçôes orçamentárias para as açôes destes programas, bem como dos demais, passaram a ser agregadas no programa "Esporte e Grandes Eventos Esportivos". Este programa contou com quatro objetivos gerais, dos quais apenas um estava voltado para as dimensões do esporte de participação e educacional. Os outros três objetivos eram referentes ao desenvolvimento do esporte de alto rendimento no país, a realização da Copa do Mundo da FIFA em 2014 e dos Jogos Olímpicos e Paralímpicos em 2016. Em 2012, o governo federal lançou o Plano "Brasil Medalhas 2016", que tinha como propósito assegurar R 1 bilhão de recursos adicionais aos esportes olímpicos e paralímpicos.

Também estamos cientes de que, além dos recursos orçamentários, o esporte de rendimento conta também com outras fontes que, tal como destacado por VERONEZ ${ }^{8}$, não sofrem cortes e contingenciamento como ocorre com as verbas que passam pelo orçamento público. Dentre estes recursos extraorçamentários, destacamos: Recursos das Estatais ${ }^{k}$, Lei Pelél, Lei Agnelo/Piva ${ }^{m}$, Lei de Incentivo ao Esporte $^{\mathrm{n}}$ e Timemania $^{\mathrm{o}}$. Deste modo, estamos cientes de que as conclusões deste estudo se limitam aos recursos orçamentários.

A predominância orçamentária dada ao "Esporte e Lazer da Cidade" no período de 2004 a 2011 também não pode ser compreendida como uma priorização da democratização do acesso ao esporte por parte do cidadão brasileiro por pelo menos duas razōes. Primeiro, porque esta política tem privilegiado ações relativas à infraestrutura esportiva, que podem ou não estar sendo usadas para a promoção do acesso ao esporte e lazer, tal como preconizado pelo programa. Segundo, porque ela tem se efetivado por meio de recursos provenientes de emendas parlamentares, que podem ou não ser renovadas a cada ano. $\mathrm{Ou}$ seja, as açôes implementadas que visam garantir o acesso às atividades esportivas e de lazer podem ser descontinuadas.

Especialmente no que se refere à política para o esporte de participação a partir do programa "Esporte e Lazer da Cidade", o fomento à prática esportiva por parte da esfera federal parece repetir 
diversos problemas de outros períodos apontados por VERONEZ ${ }^{8}$. De acordo com o autor, as açóes governamentais no setor esportivo durante os dois governos de FHC se caracterizaram por serem fragmentadas, emergenciais, tópicas e eventuais, e implementadas, em sua grande maioria, sem a garantia de fluxo de recursos para assegurar sua continuidade.

Por fim, tendemos a concordar com ATHAYDE ${ }^{10}$, o qual afirma que, "a regularidade está na ausência de padrão e na excessiva maleabilidade das prioridades governamentais, que navegam de acordo com os interesses políticos e econômicos hegemônico" (p. 302). Também concordamos com o autor, que a inexistência de uma homogeneidade nos recursos orçamentários pode ser resultado de uma descontinuidade política e administrativa, o qual nos, "impossibilita afirmar taxativamente a existência de um padrão de financiamento na política esportiva nacional e a hegemonia de uma das três dimensóes esportivas (alto rendimento, educacional e de lazer)” (p. 298 $)^{10}$. Diante da impossibilidade de identificação de um padrão ou uma área hegemônica na designação dos recursos públicos, a identificação dos objetivos da política esportiva nacional fica comprometida $^{10,11}$.

Considerando-se o preceito constitucional que estabelece o esporte como direito do cidadão e dever do Estado, destacamos a necessidade de que direitos e deveres estejam assegurados, dentre outras coisas, pelo financiamento das políticas públicas para o esporte e lazer, a partir da priorização e ampliação de programas e ações sociais em todas as etapas do processo orçamentário e no decorrer dos anos.

\section{Notas}

a. O exercício financeiro compreende o período de vigência do orçamento público. No caso brasileiro, o exercício financeiro coincide com o ano civil: de $1^{\circ}$ de janeiro a 31 de dezembro ${ }^{15}$.

b. http://www12.senado.gov.br/orcamento/sigabrasil.

c. O programa "Identidade Étnica e Patrimônio Cultural dos Povos Indígenas" que, inicialmente não constava no PPA 2004-2007 como integrante da função "Desporto e Lazer”, passou a integrar a área em decorrência da realização dos Jogos dos Povos Indígenas. Inicialmente, este programa foi designado como uma açáo multisetorial que envolveria o Ministério da Educação, Ministério da Justiça, Ministério da Saúde e Ministério do Desenvolvimento Agrário. A partir de 2005, este programa foi vinculado ao ME e passou a compor a funçáo "Desporto e Lazer".

d. O programa "Esportes de Criaçáo Nacional e de Identidade Cultural" somente constou no planejamento governamental e orçamentário em 2004.

e. O programa "Operaçóes Especiais: outros encargos especiais", implementado em 2010 e 2011, visava capitalizar a Empresa Brasileira de Legado Esportivo S.A. - Brasil 2016, a fim de promover a elaboração de estudos e projetos bem como execução e monitoramento de obras e serviços na Carteira de Projetos Olímpicos da Autoridade Pública Olímpica (APO).

f. Os órgãos setoriais são as unidades de planejamento e orçamento dos Ministérios, da Advocacia-Geral da União, da Vice-Presidência e da Casa Civil da Presidência da República ${ }^{17}$.

g. As unidades orçamentárias são entidades vinculadas ou subordinadas aos Ministérios e órgãos setoriais ${ }^{17}$.

h. As quatros açóes foram: "128X - Apoio a implantação de infraestrutura para os Jogos Olímpicos e Paraolímpicos Rio 2016”, “20D8 - Preparação e organização dos Jogos Olímpicos e Paraolímpicos Rio 2016”, “20DB - Apoio à realização da Copa do Mundo FIFA 2014”, e "20EE - Gestão e administração da Autoridade Pública Olímpica - APO”.

i. A Comissão Mista de Planos, Orçamentos Públicos e Fiscalização (CMPOF) é formada por deputados e senadores e tem como propósito apreciar e emitir pareceres sobre os projetos de lei relativos ao PPA, LDO e LOA. Além disso, também emite pareceres sobre a prestação de contas do presidente da República, sobre os planos e programas governamentais e atua no acompanhamento e a fiscalização orçamentária ${ }^{1}$.

j. O "Manual de Emendas" é um dos documentos formulados na etapa do PLOA para auxiliar os parlamentares no processo de apreciação da proposta orçamentária. Para além de instruçóes quanto às normas do processo e quanto ao uso do sistema informatizado, este documento apresenta, "exemplos de emendas, orientaçóes e recomendaçóes específicas de cada área temática ou unidade orçamentária” (p. 3) ${ }^{24}$. Ele também indica quais as açóes com maior incidência de emendas em cada área, bem como os custos médios das ações a fim de facilitar a previsão orçamentária por parte dos parlamentares. 
k. Diversas empresas estatais estabelecem patrocínios com confederações, tanto nos esportes olímpicos quanto nos paraolímpicos. Atualmente, as seguintes empresas estatais patrocinam o esporte brasileiro: Petrobras, Infraero, Eletrobrás, Correios, Caixa Econômica Federal, Banco Nacional de Desenvolvimento Econômico e Social (BNDES), Banco do Brasil e Banco do Nordeste ${ }^{55}$.

1. A Lei nº 9.615 institui que nos anos de realização dos Jogos Olímpicos e Jogos Pan-Americanos, a renda líquida de um segundo teste da Loteria Esportiva Federal será destinada ao COB e ao CPB para o atendimento da participação de delegaçóes nacionais nesses eventos esportivos ${ }^{2}$. Em 2011, a partir da promulgação da Lei no 12.395 , a Lei no 9.615 passou a incluir a Confederação Brasileira de Clubes (CBC), o qual passou a ter direito a receber recursos para a formação de atletas olímpicos e paraolímpicos ${ }^{56}$.

m. Sancionada em 16 de julho de 2011, a Lei n 10.264 prevê que $2 \%$ da arrecadação bruta das loterias federais, descontadas as premiaçóes, sejam destinadas ao $\mathrm{COB}$ e ao CBP, na seguinte proporção: $85 \%$ para o COB e $15 \%$ para o CPB. Ainda de acordo com a lei, do total arrecado por ambas instituiçôes, $10 \%$ deve ser investido no esporte escolar e 5\% no esporte universitário ${ }^{57}$. Em 06 de julho de 2015, a partir da promulgaçáo da Lei n 13,146 (Estatuto da Pessoa com Deficiência), o percentual de arrecadaçáo bruta das loterias federais passou a ser o de 2,7\%. O COB passou a contar com 62,96\% deste montante e o CPB 37,04\% ${ }^{58}$.

n. Inicialmente elaborada para o período de 2007 a 2015, a Lei nº 11.438 de 29 de dezembro de 2006 permite que pessoas físicas e jurídicas possam descontar até $6 \%$ e 1\%, respectivamente, do Imposto de Renda para aplicação, na forma de patrocínio ou doação em projetos esportivos. De acordo com a mesma, os projetos que promovam a inclusão social em comunidades de vulnerabilidade social terão prioridade ${ }^{59}$. A partir da Lei ${ }^{\circ}$. 13.155, de 4 de agosto de 2015, o prazo da lei foi prorrogado até $2022^{60}$.

o. Sancionada em 14 de setembro de 2006, a Lei nº 11.345 tem como propósito injetar 22\% da arrecadação da loteria para a regularização das dívidas dos clubes de futebol com a União ${ }^{61}$.

\title{
Agradecimentos
}

Agradecemos ao apoio financeiro da Coordenação de Coordenação de Aperfeiçoamento de Pessoal de Nível Superior (CAPES) concedido por meio de uma bolsa de estudos à primeira autora.

\section{Conflito de interesse}

Os autores declaram não haver conflitos de interesse.

\begin{abstract}
Budgetary cycle and priorities of federal sports and leisure policies in Brazil (2004-2011)

This study aimed to investigate the distribution of resources and the budget priorities of the Brazilian federal policies of the Ministry of Sports (ME) for sport and leisure over the planning processes and budget execution from 2004 to 2011. The research was quantitative and descriptive and the data were collected in the portal "SIGA Brasil". We conclude that each stage of the budget process the agreed proposal for the function "Sports and Leisure" presented specifics on what he referred to the priorities of the federal policies for sport and leisure, without a single priority framework that has guided the planning processes and budget execution. The absence of a standard in funding for the area that has permeated the different stages of the budget process and the lack of regularity in the execution of resources reveals that the federal government had not, during the period analyzed, a clear policy for the sports sector.
\end{abstract}

KeYwords: Budget; Government Financing; Public Policy; Sport. 


\section{Referências}

1. Brasil. Constituição 1988. Constituição da República Federativa do Brasil. Brasília (DF): Senado; 1988.

2. Brasil. Lei n. 9615 de 24 de março de 1998. Institui normas gerais sobre desporto e dá outras providências. Diário Oficial União, Brasília (1998 mar. 25); Sec.1:1.

3. Almeida BS, Coakley J, Marchi Júnior W, Starepravo FA. Federal government funding and sport: the case of Brazil, 2004-2009. International Journal of Sport Policy and Politics. 2012;4(3):411-426.

4. Almeida BS, Marchi Júnior W. O financiamento dos programas federais de esporte e lazer no Brasil (2004 a 2008). Movimento. 2010; 16:73-92.

5. Bueno L. Políticas Públicas do esporte no Brasil: razóes para o predomínio do alto rendimento [tese]. São Paulo (SP): Fundação Getúlio Vargas; 2008.

6. Castro SBE, Starepravo FA, Coakley J, Souza DL. Mega sporting events and public funding of sport in Brazil (20042011). Leisure Studies. 2016;35(3):369-386.

7. Neves COB, Silva MRS. O financiamento do esporte pelo Governo Federal em 2007. In: Silveira JFB, Hecktheuer LFA, Silva MRS, organizadores. Circo, lazer e esporte: políticas públicas em jogo. Rio Grande: Universidade Federal do Rio Grande; 2011. p. 115-143.

8. Veronez LFC. Quando o Estado joga a favor do privado: as políticas de esporte após a Constituição de 1988 [tese]. Campinas (SP): Universidade Estadual de Campinas; 2005.

9. Athayde PFA. A disputa pelo fundo público no âmbito do financiamento esportivo brasileiro. Rev Bras Ciênc Esporte. 2014;36:S636-S651.

10. Athayde PFA. O ornitorrinco de chuteiras: determinantes econômicos da política de esporte do governo Lula e suas implicações sociais [tese]. Brasília (DF): Universidade de Brasília; 2014.

11. Athayde PFA, Mascarenhas F, Salvador E. Primeiras aproximaçôes de uma análise do financiamento da política nacional de esporte e lazer no governo Lula. Rev Bras Ciênc Esporte. 2015;37:2-10.

12. Castelan LP. As Conferências Nacionais do Esporte na configuração da política esportiva e de lazer no governo Lula (2003-2010) [dissertação]. Campinas (SP): Universidade Estadual de Campinas; 2011.

13. Assis LGB. Processo legislativo e orçamento público: a função de controle do parlamento [tese]. São Paulo (SP): Universidade de São Paulo; 2009.

14. Amaral SCF, Ribeiro OCF, Silva DS. Produção científico-acadêmica em políticas públicas de esporte e lazer no Brasil. R Motriviv. 2014;26:27-40.

15. Orçamento Federal [homepage]. Brasília: Senado Federal; 2016 [citado jan. 2016]. Disponível em: http://www12. senado.gov.br/orcamento/glossario.

16. Kanayama RL, Rodrigues DLC. A política e o orçamento público: desequilíbrios no fiel da balança. Revista MPC PR. 2015;1:48-61.

17. Brasil. Lei n. 10180 de 06 de fevereiro de 2001. Organiza e disciplina os Sistemas de Planejamento e de Orçamento Federal, de Administração Financeira Federal, de Contabilidade Federal e de Controle Interno do Poder Executivo Federal, e dá outras providências. Diário Oficial da União, Brasília (2001 fev. 7); Sec.1:2.

18. Cota Júnior GA, Rodrigues RVA, Souza FMP, Fonseca GPS. Emendas parlamentares: a relação entre o Executivo e o Legislativo em Minas Gerais. VIII Congresso CONSAD de Gestão Pública; 26-28 maio 2015; Brasília, Brasil. Brasília: CONSAD; 2015.

19. Perreira C, Mueller B. Comportamento estratégico em presidencialismo de coalizão: as relaçóes entre Executivo e Legislativo na elaboração do orçamento brasileiro. Dados. 2002;45:265-301.

20. Rezende F, Cunha A. Contribuintes e cidadãos: compreendendo o orçamento federal. Rio de Janeiro: Editora da FGV; 2002.

21. Matias WB. O enigma olímpico: o controvertido percurso da agenda e políticas esportivas no governo Lula [dissertação]. Brasília (DF): Universidade de Brasília; 2013.

22. Limongi A, Figueiredo F. Processo orçamentário e comportamento legislativo: emendas individuais, apoio ao executivo e programas de governo. Dados. 2005;48:737-776.

23. Brasil. Congresso Nacional. Comissão Mista de Planos, Orçamentos Públicos e Fiscalização. Projeto de lei orçamentária anual para 2004 - Área temática VI: Educação, Ciência e Tecnologia, Cultura e Esporte - Relatório. Brasília: Congresso Nacional; 2003.

24. Brasil. Congresso Nacional. Comissão Mista de Planos, Orçamentos Públicos e Fiscalização. Processo orçamentário 
para 2007: instruçóes para elaboração de emendas aos PL 15 e 16/2006-CN. Brasília: Congresso Nacional; 2006.

25. Brasil. Congresso Nacional. Comissão Mista de Planos, Orçamentos Públicos e Fiscalização. Processo orçamentário para 2005: instruçôes para elaboração de emendas ao projeto de lei orçamentária para 2005. Brasília: Congresso Nacional; 2004.

26. Brasil. Ministério do Planejamento, Orçamento e Gestão. Secretaria de Planejamento e Investimentos Estratégicos. Relatório de avaliação do plano plurianual 2004-2007- ano base 2005: Caderno 19 - Ministério do Esporte. Brasília: Ministério do Planejamento, Orçamento e Gestão; 2006.

27. Starepravo FA. Políticas públicas de esporte e lazer no Brasil: aproximaçôes, intersecçóes, rupturas e distanciamentos entre os subcampos político/burocrático e científico/acadêmico [tese]. Curitiba (PR): Universidade Federal do Paraná; 2011.

28. Brasil. Ministério do Planejamento, Orçamento e Gestão. Secretaria de Planejamento e Investimentos Estratégicos. Relatório de avaliação do plano plurianual 2008-2011- ano base 2008: Caderno 19 - Ministério do Esporte. Brasília: Ministério do Planejamento, Orçamento e Gestão; 2009.

29. Souza C. Federalismo e conflitos distributivos: disputa dos estados por recursos orçamentários federais. Dados. 2003;46:345-384.

30. Brasil. Lei n. 4320 de 17 de março de 1964. Estatui Normas Gerais de Direito Financeiro para elaboração e controle dos orçamentos e balanços da União, dos Estados, dos Municípios e do Distrito Federal. Diário Oficial da União, Brasília (1964 mar. 23); Sec.1:2745.

31. Silva JC. A Lei n. 4320/64 comentada: uma contribuição para a elaboração da lei complementar. Brasília: Thesaurus; 2007.

32. Whitson D, Horne J. Underestimated costs and overestimated benefits? Comparing the outcomes of sports mega-events in Canada and Japan. The Sociological Review. 2006;54:73-89.

33. Brasil. Presidência da República. Prestação de Contas do Presidente da República. Exercício 2008. 5.17 - Ministério do Esporte. Brasília: Presidência da República; 2009.

34. Brasil. Presidência da República. Prestação de Contas do Presidente da República. Exercício 2004 . 17 - Ministério do Esporte - ME. Brasília: Presidência da República; 2005.

35. Brasil. Presidência da República. Prestação de Contas do Presidente da República. Exercício 2005. 17 - Ministério do Esporte - ME. Brasília: Presidência da República; 2006.

36. Brasil. Presidência da República. Prestação de Contas do Presidente da República. Exercício 2006. 6.18 - Ministério do Esporte - ME. Brasília: Presidência da República; 2007.

37. Brasil. Presidência da República. Prestação de Contas do Presidente da República. Exercício 2007. 6.18 - Ministério do Esporte - ME. Brasília: Presidência da República; 2008.

38. Brasil. Presidência da República. Prestação de Contas do Presidente da República. Exercício 2009. 5.17 - Ministério do Esporte. Brasília: Presidência da República; 2010.

39. Brasil. Presidência da República. Prestação de Contas do Presidente da República. Exercício 2010. 5.1 .18 - Função Desporto e Lazer. Brasília: Presidência da República; 2011.

40. Brasil. Ministério do Planejamento, Orçamento e Gestão. Secretaria de Planejamento e Investimentos Estratégicos. Relatório de avaliação do plano plurianual 2004-2007- ano base 2006: Caderno 19 - Ministério do Esporte. Brasília: Ministério do Planejamento, Orçamento e Gestão; 2007.

41. Oliveira MM. Políticas públicas de esporte no Brasil e ONG: par eles ganham, ímpar nós perdemos [dissertação]. Salvador (BA): Universidade Federal da Bahia; 2013.

42. Starepravo FA, Mezzadri FM, Marchi Júnior W. Criação e mudanças na estrutura do Ministério do Esporte do Brasil: tensões nas definiçóes de espaços. Rev Bras Educ Fís Esporte. 2015;29:217-228.

43. Brasil. Ministério do Esporte. Esporte, lazer e desenvolvimento humano - texto final da I Conferência Nacional do Esporte. Brasília: Ministério do Esporte; 2004.

44. Brasil. Ministério do Esporte. II Conferência Nacional do Esporte - Texto básico. Brasília: Ministério do Esporte; 2006.

45. Brasil. Ministério do Esporte. III Conferência Nacional do Esporte - Texto Básico. Brasília: Ministério do Esporte; 2010.

46. Brasil. Emenda Constitucional n. 86 de 17 de março 2015. Altera os arts. 165, 166 e 198 da Constituição Federal, para tornar obrigatória a execução da programação orçamentária que especifica. Diário Oficial da União, Brasília (2015 mar. 18); Sec. 1:1.

47. Mascarenhas F. Financiamento do esporte. Sistema Nacional do Esporte em construção: sistemas públicos nacionais 
e modelos esportivos internacionais; 24 jun. 2015; Brasília, Brasil. Brasília: Ministério do Esporte; 2015.

48. Santo ES. Governos estaduais e descentralização do Programa Segundo Tempo: uma análise descritiva do desempenho (2003 a 2012). 9 Encontro ABCP; 4-7 ago. 2014; Brasília, Brasil. Rio de Janeiro (RJ): ABCP; 2014.

49. Santos ES, Starepravo FA, Souza Neto MS. Programa "Segundo Tempo" e o vazio assistencial na região Nordeste. Movimento. 2015;21:759-771.

50. Linhales MA. A trajetória política do esporte no Brasil: interesses envolvidos, setores excluídos [dissertação]. Belo Horizonte (MG): Universidade Federal de Minas Gerais; 1996.

51. Melo Filho A. O desporto na ordem jurídico-constitucional brasileira. São Paulo: Malheiros Editores; 1995.

52. Mendes MJ. Sistema orçamentário brasileiro: planejamento, equilíbrio fiscal e qualidade do gasto público. Brasília: Consultoria Legislativa do Senado Federal; 2008.

53. Brasil. Ministério do Planejamento, Orçamento e Gestão. Secretaria de Planejamento e Investimentos Estratégicos. Relatório de avaliação do plano plurianual 2004-2007- ano base 2007: Caderno 19 - Ministério do Esporte. Brasília: Ministério do Planejamento, Orçamento e Gestão; 2008.

54. Almeida BS. Altius, citius, fortius... Ditius? Lógicas e estratégias do Comitê Olímpico Internacional, Comitê de Candidatura e Governo brasileiro na candidatura e escolha dos Jogos Olímpicos e Paralímpicos Rio 2016 [tese]. Curitiba (PR): Universidade Federal do Paraná; 2015.

55. Brasil. Portal Brasil 2016 [homepage]. Brasil: Rede Nacional do Esporte; 2015. Portal oficial do governo federal sobre os Jogos Olímpicos e Paralímpicos de 2016 [citado 2015]. Disponível em: http://www.brasil2016.gov.br/pt-br.

56. Brasil. Lei n. 12395 de 16 de março de 2011. Altera as Leis nos 9.615, de 24 de março de 1998, que institui normas gerais sobre desporto, e 10.891, de 9 de julho de 2004, que institui a Bolsa-Atleta; cria os Programas Atleta Pódio e Cidade Esportiva; revoga a Lei no6.354, de 2 de setembro de 1976; e dá outras providências. Diário Oficial da União, Brasília (2011 mar. 17); Sec.1:1.

57. Brasil. Lei n. 10264 de 16 de julho de 2001. Acrescenta inciso e parágrafos ao art. 56 da Lei no 9.615, de 24 de março de 1998, que institui normas gerais sobre desporto. Diário Oficial da União, Brasília (2001 jul. 17); Sec.1:1.

58. Brasil. Lei n. 13146 de 06 de julho de 2015. Institui a Lei Brasileira de Inclusão da Pessoa com Deficiência (Estatuto da Pessoa com Deficiência). Diário Oficial da União, Brasília (2015 jul. 7). Sec.1:2.

59. Brasil. Lei n. 11438 de 29 de dezembro de 2006. Dispóe sobre incentivos e benefícios para fomentar as atividades de caráter desportivo e dá outras providências. Diário Oficial da União, Brasília (2006 dez. 29); Sec.1:1.

60. Brasil. Lei n. 13155 de 04 de agosto de 2015. Estabelece princípios e práticas de responsabilidade fiscal e financeira e de gestão transparente e democrática para entidades desportivas profissionais de futebol; institui parcelamentos especiais para recuperação de dívidas pela União, cria a Autoridade Pública de Governança do Futebol - APFUT; dispóe sobre a gestão temerária no âmbito das entidades desportivas profissionais; cria a Loteria Exclusiva - LOTEX; altera as Leis nos 9.615, de 24 de março de 1998, 8.212, de 24 de julho de 1991, 10.671, de 15 de maio de 2003, 10.891, de 9 de julho de 2004, 11.345, de 14 de setembro de 2006, e 11.438, de 29 de dezembro de 2006, e os Decretos-Leis nos 3.688, de 3 de outubro de 1941, e 204, de 27 de fevereiro de 1967; revoga a Medida Provisória no 669, de 26 de fevereiro de 2015; cria programa de iniciação esportiva escolar; e dá outras providências. Diário Oficial da União, Brasília (2015 ago. 5); Sec. 1:1.

61. Brasil. Lei n. 11345 de 14 de setembro de 2006. Dispóe sobre a instituição de concurso de prognóstico destinado ao desenvolvimento da prática desportiva, a participação de entidades desportivas da modalidade futebol nesse concurso e o parcelamento de débitos tributários e para com o Fundo de Garantia do Tempo de Serviço - FGTS; altera as Leis nos 8.212, de 24 de julho de 1991, e 10.522, de 19 de julho de 2002; e dá outras providências. Diário Oficial da União, Brasília (2006 set. 15); Sec.1:1.

ENDEREÇO DE CORRESPONDÊNCIA: Suélen Barboza Eiras de Castro

Rua Coração de Maria, 92

Curitiba - Paraná - BRASIL

CEP: 80210-132

E-mail: sueleneiras@hotmail.com
Submetido: 10/06/2016

Revisado: 08/02/2018

Aceito: 26/09/2018 